\title{
Body Mechanics and Complications in the Nursing Personnel of the Emergency Service of Luis Vernaza General Hospital (Guayaquil- Ecuador)
}

\author{
María Olalla ${ }^{1}$, Gladys Naranjo ${ }^{1}$, Silvana López ${ }^{1}$, Maura Muñoz ${ }^{1}$, Favian Bayas-Morejón ${ }^{2 *}$
}

\author{
${ }^{1}$ Universidad Estatal de Bolívar, Facultad de Ciencias de la Salud y del Ser Humano, Carrera de Enfermería, CP: 020150, Guaranda, ECUADOR \\ ${ }^{2}$ Universidad Estatal de Bolívar, Facultad de Ciencias Agropecuarias Recursos Naturales y del Ambiente, Departamento de Investigación, CP: 020150, Guaranda, \\ ECUADOR \\ *Corresponding Author: fbayas@ueb.edu.ec isba@doctor.upv.es
}

Citation: Olalla M, Naranjo G, López S, Muñoz M, Bayas-Morejón F. Body Mechanics and Complications in the Nursing Personnel of the Emergency Service of Luis Vernaza General Hospital (Guayaquil-Ecuador). Electron J Gen Med. 2020;17(2):em192. https://doi.org/10.29333/ejgm/7809

\begin{abstract}
ARTICLE INFO
Received: 14 Sep. 2019

Accepted: 4 Jan. 2020

ABSTRACT

The mobilization and transport of patients, repetitive movements, prolonged standing work, and lack of rest due to double work in the majority, are important risk factors that produce in nursing work. If this is added to an inadequate posture and incorrect application of the principles of body mechanics, the risk increases. The objective of this study was to determine the causes of complications related to the non-correct application of body mechanics in nursing personnel. To this end, the research question is: with the incorrect application of body mechanics increases the complications presented by the nursing staff working in this service. The responses received show that the staff is aware of body procedure techniques that do not apply and that most have nervous complications. Taking into account the above, frequent training of nurses is recommended, as well as the use of the manual of ergonometric techniques that guarantees the conservation of health.
\end{abstract}

Keywords: body mechanics, complications, ergonomic, techniques, LVHG

\section{INTRODUCTION}

The WHO prescribes that, in all employees and workers, health must be promoted and protected through prevention, control of diseases, accidents, and the elimination of factors and conditions that endanger health and safety at work; therefore, it must always promote safe work, as well as adequate environments, work organizations that enhance the physical, mental and social well-being of workers, supporting the improvement and maintenance of their work capacity $(1,2)$.

In nursing work, multiple tasks are developed where the correct application of body mechanics in the mobilization and transport of patients is required; days of 8 and 12 hours long work demand of the nursing professional to fulfill their functions, activities and tasks standing, repetitive movements and limited rest as well as double working hours, affect as risk factors of bone, muscle, Articular and tendinous, that with years of work and an inadequate application of the principles of body mechanics become a latent risk for the health of the nursing professional. We know that the hospital environment is made up of a multidisciplinary health team, with Nursing being the main axis in the direct care of patients; for which, the development of adequate techniques of body mechanics is required $(3,4)$.

Currently it is known that $84.4 \%$ of nursing staff have musculoskeletal diseases one or more times in their life; In a study of a 12-month period, a point prevalence rate (of musculoskeletal diseases, in any region of the body) was presented between 66.1 and $78 \%$. Musculoskeletal diseases were concentrated in the lower back $(44.1 \%)$, neck $(28.0 \%)$, and knees (22.4\%); of them $30.3 \%$ were treated or had visited other health professionals for care (5).

Based on a situational diagnosis of the body mechanics applied by the Nursing staff of the emergency service of the Luis Vernaza General Hospital, the health problems derived from this activity were identified; In addition, through the application of the observation guide, the patient care techniques were determined in which the nursing staff does not comply with the ergonomic norms of body mechanics; the information obtained has allowed the elaboration of a manual of ergonometric techniques for nursing personnel.

\section{METHODS}

The research was carried out with the participation of the nursing staff of the emergency service of the Luis Vernaza Hospital in the city of Guayaquil (LVHG), for which, body mechanics were evaluated to 121 nurses and nursing auxiliaries in the period October 2012 - June 2013.

Of the total of 121 , of the nursing staff (licensed and auxiliary) who worked in the emergency service, we worked with a universe of 70 , because our research was directed to the personnel that provides direct care to the user applying the technique of the body mechanics. 
The data collection techniques that prevailed were: surveys directed to the Nursing professional and Nursing Assistants who worked in the ICU 2 and Resuscitation to determine the complications of the application of body mechanics in direct care to the user, with the respective review of statistical data of nursing staff schedules.

Direct observation guide in the application of the techniques of body mechanics of nursing personnel used in direct care to the user in the different shifts (morning, afternoon and evening) in the areas of ICU 2 and Resuscitation.

The information obtained through the application of the survey and the observation guide mentioned above were analyzed in a computer processor using the following programs: Word, Excel, and statistical package, using frequency tables and graphs to facilitate their interpretation and analysis.

\section{RESULTS AND DISCUSSION}

The profession of Nursing complies with work 24 hours / day, 365 days / year, in rotating schedules; providing assistance to patients for which they must perform different procedures involving the mobilization of equipment and heavy supplies, in addition to repetitive exercises, transportation of the resuscitation car, medication, healing, aspiration of secretions, direct patient care, flexion and extension of the trunk when executing movement and exercise techniques to the bedridden user (6). In addition, the staff must stretch and flex the limbs to transport equipment stored in packages of approximately 20 $\mathrm{kg}$.

Through the observation made it is evident that $70 \%$ of the nursing professionals do not comply with the correct application of the body mechanics or perform it in certain activities such as use the arms as levers to increase the lifting force for mobilization of patients; They try to use sheets to mobilize the disabled patient, they begin the movements with correct alignment, they keep as close as possible the object to move, they separate their body from the line of gravity, they avoid stretching, turns of the base of support, alternating periods of rest and activity when moving objects or users; as well as to move objects they expand their base of support, flexing the knees, hips and ankles to lift weights, distribute the loads in both arms and legs to push an object, place forward the foot to move or load objects keeping them close to their gravity center.

Research shows that of the 19 basic principles of Body Mechanics in the care of the user, 13 parameters are not met by the nursing staff working in these areas with musculoskeletal and nervous complications in the short and long term that are not yet evident. for being eminently young staff giving little importance to the correct application of the techniques of body mechanics, despite having knowledge of the subject and its impact on health.

However, there is a $30 \%$ of the nursing staff that work in the areas of ICU 2 and Resuscitation, they apply the basic principles of body mechanics, such as the fulfillment of the following activities: carefully organize the displacement or change of site, clear the obstacle area and place the necessary equipment near the bed (feet or head), get help from other people, stay in front of the direction of movement to move objects pull, push or rotate and lower the head of the user's bed before incorporating it.

The Regulation of the Conditions of Hygiene and Safety at Work (1973) in its Article 223 states that "in no case may a worker carry more than $50 \mathrm{~kg}$, nor a worker weigh more than 20 kg."; so, it is important that nurses exposed to physical overload consider preventive measures to avoid back disorders, specifically the back - lumbar (7).

Polo and Villena (8), Peru, carried out an investigation on the "Level of knowledge about corporal mechanics and its application in the care of the patient postrate by nursing interns H.R.D.T - 2011" of quantitative, descriptive, correlation nature. The results that were obtained regarding the application of body mechanics was that $70.9 \%$ applied it inadequately.

Taking into account the above, frequent training of nurses is recommended, as well as the use of the manual of ergonometric techniques that guarantees the conservation of health.

\section{REFERENCES}

1. Arenas-Massa Á, Riveros-Ferrada C. Aspectos éticos y jurídicos de la salud ocupacional. pers. bioét. 2017;21(1):62-77. https://doi.org/10.5294/pebi.2017.21.1.5

2. Matabanchoy Tulcán S. Salud en el trabajo. Univ. Salud. 2012;14(1):87-102.

3. Ibrahim R, Elsaay O. The Effect of Body Mechanics Training Program for Intensive Care Nurses in Reducing Low Back Pain. IOSR Journal of Nursing and Health Science; 2015;4(5):81-96.

4. von Kodolitsch $\mathrm{Y}$, Rybczynski M, Vogler M, et al. The role of the multidisciplinary health care team in the management of patients with Marfan syndrome. J Multidiscip Healthc 2016;9:587-614. https://doi.org/10.2147/JMDH.S93680 PMid:27843325 PMCid:PMC5098778

5. Zacarías F, González. Bases científicas de la enfermera, 2nd. Ed; 2009. p. 157.

6. Dalri R de $C$ de MB, Silva LA da, Mendes AMOC, Robazzi ML do CC. Nurses' workload and its relation with physiological stress reactions. Rev Lat Am Enfermagem. diciembre de 2014;22(6):959-65. https://doi.org/10.1590/0104-1169. 3292.2503 PMid:25591090 PMCid:PMC4309230

7. Kosier B, Erb G, Blais K, Wilkinson JM. Fundamentos de Enfermería conceptos, proceso y práctica, 5ta. Ed. actualizada. Ed. McGraw Hill. Interamericana. México D.F. España; 2010:155-9.

8. Polo M, Villena O. Nivel de conocimiento sobre mecánica corporal y su aplicación en el cuidado del paciente postrado por internas de enfermería. [graduate thesis]. H.R.D.T. Perú; 2012. 